\title{
A Case of Mesothelial Cystic Mediastinal Mass
}

Quratulain Fatima Masood ${ }^{1 *}$, Ali Asad ${ }^{2}$, Maira Nusrat ${ }^{2}$, Umair Hamid ${ }^{2}$, Muhammad Hasib Khalil ${ }^{2}$, Hasan Raza Hashmi $^{3}$, Irbaz Ahmed ${ }^{3}$, Sara Habib, Arham Hiran , Fiaz Hussain ${ }^{5}$, Saad Javaid ${ }^{5}$, Maira Shahid ${ }^{6}$, Faryal Ali ${ }^{6}$, Fnu Sandeep $^{6}$, Atif Ibrahim ${ }^{7}$, Hamza Bajwa ${ }^{8}$, Amna Ejaz $^{8}$, Moeed Ahmed ${ }^{8}$, Hafiz Zarsham Ali Ikram ${ }^{8}$, Amar Lal $^{9}$ and $^{-}$ Wardah Siddiq ${ }^{10}$

${ }^{1}$ National University of Science and Technology, Pakistan

${ }^{2}$ University of Health Sciences Lahore, Pakistan

${ }^{3}$ Agha Khan University Karachi, Pakistan

${ }^{4}$ Ziauddin University, Pakistan

${ }^{5}$ Nishtar Medical University Multan, Pakistan

${ }^{6}$ Dow University of Health Sciences, Pakistan7Ayub Medical College, Khyber University Peshawar, Pakistan

${ }^{8}$ King Edward Medical University Lahore, Pakistan

${ }^{9}$ Research Assistant, University of Arizona, USA

${ }^{10}$ Army Medical College Pakistan, Pakistan

Submission: April 30, 2018; Published: May 09, 2018

*Corresponding author: Quratulain Masood, National University of Sciences and Technology, Karachi, Pakistan, Email: quratulain.fatima@gmail.com

\section{Case}

A 65 year old woman presented with vague chest pain and shortness of breath. General physical and systemic examinations were unremarkable. Chest X-Ray showed a large mass in the anterio-superior mediastinum. Computed Tomography (CT) Scan showed a well-defined soft tissue mass with broad base towards the pleura in the right upper lung zone measuring 7.9X7.5X7 in transverse, crainio-caudal and AP dimensions, respectively. CTguided Fine needle aspiration biopsy was done which was nondiagnostic. Bacterial cultures and AFT cultures turned out to be negative. Median sternotomy was done, and the entire mass was excised. The excised mass was sent for histopathology. The FNA was not diagnostic. The histopathology proved it to be primary mesothelial cyst of the mediastinum. The patient made uneventful recovery postoperatively.

\section{Discussion}

Primary cysts of mediastinum include bronchogenic cysts, enteric or duplication cysts, mesothelial cysts, thymic cysts, and thoracic duct cysts [1]. Mesothelial cysts are fluid filled sacs lined by Mesothelial cells [2]. They are usually unilocular and can be found in various sites like liver [3], round ligament [4], pericardium [5], peritoneal cavity [6], spermatic cord [7], adrenal gland [8] kidney [9] and spleen [10]. Intrathoracic mesothelial cysts are congenital lesions due to an anomaly in the development of the pericardial coelom [11]. They are classically located in the anterior cardiophrenic angle but rarely can they be found elsewhere in the paravertebral region, the anterior mediastinum [12] or the paratracheal regions [13]. Mesothelial cysts include a variety that has been reported as pleuropericardial, pleural and simple mesothelial cysts.

Pathologically, the cyst wall consists of a single layer of flattened endothelial cells with an underlying connective tissue stroma. They are often detected as an abnormal shadow on routine chest x-ray films, occurring at an incidence of 1 in 100,000 [14]. As reported by two old case series, they are located in the right cardio-phrenic angle in $51 \%-71 \%$ of cases, and in the left cardiophrenic angle in $22 \%-38 \%$ of cases $[15,16]$. Surgical resection is the ideal treatment of these lesions, and is classically performed by thoracotomy $[17,18]$. Mesothelial cystic mediastinal mass is considered as a rare mesothelioma.

\section{References}

1. Awad WI, AG Nicholson, P Goldstraw (2001) Concurrent cysts of the mediastinum, pleura and neck. Eur J Cardiothorac Surg 20(4): 861-863.

2. Augustine AJ, Pai RK, Pai R, Diaz EA, Prabhu HS, et al. (2001) Mesothelial cyst at porta hepatis. Indian J Gastroenterol 20(1): 35-36.

3. Komori K, Hoshino K, Shirai J, Morikawa Y (2008) Mesothelial cyst of the liver in a neonate. Pediatr Surg Int 24(4): 463-435.

4. Kim BM, Lee JY, Han YH, Kim SY, Seo JW, et al. (2010) Mesothelial cyst of the round ligament mimicking a metastasis: a case report. Korean J Radiol 11(3): 364-367. 
5. Comoglio C, Sansone F, Delsedime L, Campanella A, Ceresa F, et al., (2010) Mesothelial cyst of the pericardium, absent on earlier computed tomography. Tex Heart Inst J 37(3): 354-357.

6. Ramirez Y, J Rosai, JJ Segura (2010) Loose mesothelial cysts in the peritoneal cavity. Int J Surg Pathol 18(3): 214-216.

7. Vaos, G, Zavras N, Velaoras K, Ereikat K (2009) Muesothelial cyst of the spermatic cord as a cause of acquired cryptorchidism. Hernia 13(4): 439-441.

8. Suh J, A Heimann, H Cohen (2008) True adrenal mesothelial cyst in a patient with flank pain and hematuria: a case report. Endocr Pathol 19(3): 203-205

9. Calabro G, Pappalardo S, Calabrò V, Pizzarelli M, Spampinato A, et al. (2008) [Mesothelial cyst of the kidney. A rare case report of this neoformation on the left kidney]. Urologia 75(1): 116-118.

10. Czauderna P, Vajda P, Schaarschmidt K, Kalman A, Jainsch M, et al (2006) Nonparasitic splenic cysts in children: a multicentric study. Eur J Pediatr Surg 16(6): 415-419.

This work is licensed under Creative Commons Attribution 4.0 License

DOI: 10.19080/JAICM.2018.06.555695
11. TW S (2000) General Thoracic Surgery. ( $5^{\text {th }}$ edn.), Lippincott Williams and Wilkins: Philadelphia. pp. 2423-2425.

12. Jamplis RW, GA Lillington, W Mills (1963) Pleural cysts simulating mediastinal tumors. JAMA 185: 727-728.

13. Urschel JD, TA Horan (1994) Mediastinoscopic treatment of mediastinal cysts. Ann Thorac Surg, 58(6): 1698-1701.

14. Roux BTL (1959) Pericardial Coelomic Cysts. Thorax 14: 27-34.

15. Feigin DS, Fenoglio JJ, McAllister HA, Madewell JE (1977) Pericardial cysts. A radiologic-pathologic correlation and review. Radiology 125(1): 15-20.

16. Grundmann G, FR, Grusser G (1955) Kongenitale herneutelkystem Thorax-chirurgie 2(492).

17. Cangemi, V (1999) Pericardial cysts of the mediastinum. J Cardiovasc Surg (Torino) 40(6): 909-913.

18. Kutlay H (2001) Atypically located pericardial cysts. Ann Thorac Surg 72(6): 2137-2139.

Your next submission with Juniper Publishers will reach you the below assets

- Quality Editorial service

- Swift Peer Review

- Reprints availability

- E-prints Service

- Manuscript Podcast for convenient understanding

- Global attainment for your research

- Manuscript accessibility in different formats

( Pdf, E-pub, Full Text, Audio)

- Unceasing customer service

Track the below URL for one-step submission https://juniperpublishers.com/online-submission.php 